\title{
Osmotic water permeability of plasma and vacuolar membranes in protoplasts I. High osmotic water permeability in radish (Raphanus sativus) root cells as measured by a new method
}

\author{
Mari Murai-Hatano - Tsuneo Kuwagata
}

Published online: 24 February 2007

(C) The Botanical Society of Japan and Springer 2007

\section{Erratum to: J Plant Res}

\section{DOI: 10.1007/s10265-006-0035-2}

During correction of the above-mentioned article, an error was inadvertently introduced into the column headings of Table 2. Corrected Table 2 is as follows:

Table 2 Calculations of $P_{f 1}$ by using the three-compartment model. $P_{f 1}$ was determined from the relationship between $R_{P(\text { bulk })} / R_{P 2}$ and $R_{P(\text { bulk })} /\left(R_{P 1}+R_{P 2}\right)$, as a function of $\alpha_{0}\left(=r_{20} / r_{10}\right)$ and $\beta_{10}$ which is shown in Fig. $7 \mathrm{~b}$ in Kuwagata and Murai-Hatano (2007). $R_{P(\text { bulk })}, R_{P 1}$ and $R_{P 2}$ denote $1 / P_{f(\text { bulk })}, 1 / P_{f 1}$ and $1 / P_{f 2}$, respectively

\begin{tabular}{|c|c|c|c|c|c|c|c|c|c|}
\hline $\begin{array}{l}\text { Data } \\
\text { source }\end{array}$ & $\begin{array}{l}C_{00} \\
\mathrm{~mol} \mathrm{~m}^{-3}\end{array}$ & $\begin{array}{l}C_{0+} \\
\mathrm{mol} \mathrm{m}^{-3}\end{array}$ & $\alpha_{0}$ & $\beta_{10}$ & $\begin{array}{l}P_{f(\text { bulk })}^{\text {ex }} \\
10^{-6} \mathrm{~m} \mathrm{~s}^{-1}\end{array}$ & $\begin{array}{l}P_{f 2}^{\mathrm{ex}} \\
10^{-6} \mathrm{~m} \mathrm{~s}^{-1}\end{array}$ & $\begin{array}{l}R_{P(\text { bulk })}^{\text {ex }} / \\
R_{P 2}^{\text {ex }}\end{array}$ & $\begin{array}{l}R_{P(\text { bulk })}^{\text {ex }} / \\
\left(R_{P 1}^{\mathrm{ex}}+R_{P 2}^{\mathrm{ex}}\right)\end{array}$ & $\begin{array}{l}P_{f 1}^{\mathrm{ex}} \\
10^{-6} \mathrm{~m} \mathrm{~s}^{-1}\end{array}$ \\
\hline Fig. $6^{* 1}$ & 300 & 450 & 0.95 & 0.675 & 290 & 530 & 1.83 & 0.891 & 500 \\
\hline Table $1^{* 2}$ & 300 & 450 & 0.95 & $0.670^{* 3}$ & 360 & 600 & 1.67 & 0.877 & 670 \\
\hline Table $1^{* 2}$ & 225 & 450 & 0.95 & $0.510^{* 3}$ & 340 & 540 & 1.59 & 0.875 & 660 \\
\hline
\end{tabular}

These calculations are based on the assumption $P_{f}=$ constant during shrinking of protoplasts and vacuoles (model 1)

${ }^{*} 1$ The $P_{f 1}^{\text {ex }}$ value was calculated from the values of $P_{f(\text { bulk })}^{\text {ex }}$ and $P_{f 2}^{\text {ex }}$ measured on the same protoplast shown in Fig. 6

${ }^{* 2}$ The $P_{f 1}^{\mathrm{ex}}$ values were calculated from the averaged values of $P_{f(\mathrm{bulk})}^{\mathrm{ex}}$ and $P_{f 2}^{\mathrm{ex}}$ shown in the Table 1

${ }^{* 3}$ These values were average of $\beta_{10}$ data of protoplasts shown in Table 1

The online version of the original article can be found at http://dx.doi.org/10.1007/s10265-006-0035-2.

M. Murai-Hatano ( $\square)$

National Agricultural Research Center for the Tohoku

Region, Morioka 020-0198, Japan

e-mail: murai@affrc.go.jp

T. Kuwagata

National Institute for Agro-environmental Sciences,

Tsukuba 305-8604, Japan 